
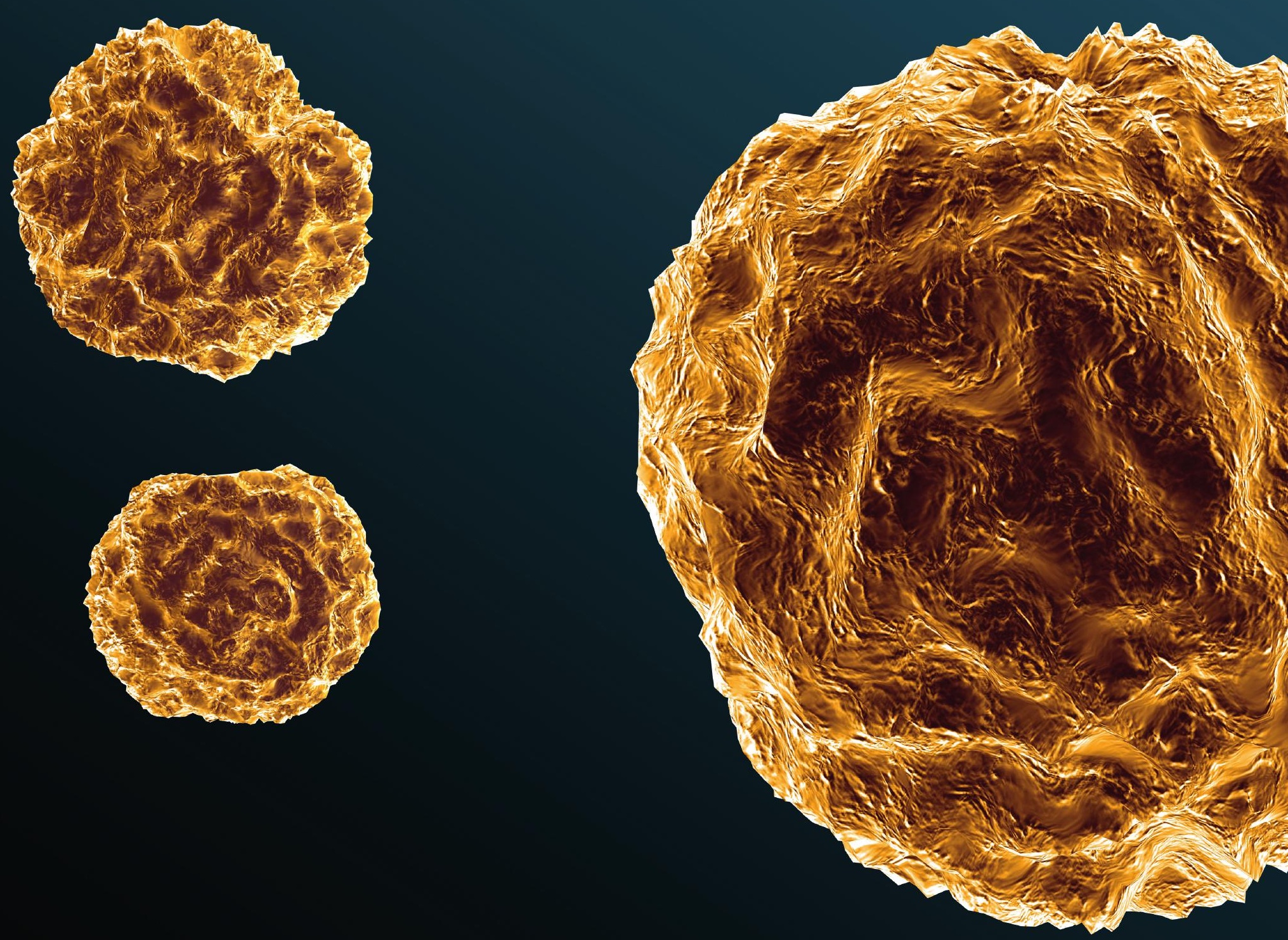

\title{
Beoordeling gipsmonsters voor toepassing op landbouwgrond
}

P.J.L. Derikx, H. Heskamp, B. van de Kooi 



\section{Beoordeling gipsmonsters voor toepassing op landbouwgrond}

P.J.L. Derikx, H. Heskamp, B. van de Kooi

Dit onderzoek is uitgevoerd door Wageningen Food Safety Research, instituut binnen de rechtspersoon Stichting Wageningen Research, in opdracht van en gesubsidieerd door NVWA onder contractnummer 2033172. 
Derikx, P.J.L., Heskamp, H., van de Kooi, B., 2021. Beoordeling gipsmonsters voor toepassing op landbouwgrond. Wageningen, Wageningen Food Safety Research, WFSR-rapport 2021.013. 18 blz.; 1 fig.; 3 tab.; 0 ref.

Projectnummer: 1207131101

Projecttitel: Beoordeling gipsmonsters in het kader van toepassing op landbouwgrond

Projectleider: P.J.L. Derikx

Dit rapport is gratis te downloaden op https://doi.org/10.18174/550516 of op http://www.wur.nl/food-safety-research (onder WFSR publicaties).

(C) 2021 Wageningen Food Safety Research, instituut binnen de rechtspersoon Stichting Wageningen Research. Hierna te noemen WFSR.

Het is de opdrachtgever toegestaan dit rapport integraal openbaar te maken en ter inzage te geven aan derden. Zonder voorafgaande schriftelijke toestemming van het WFSR is het niet toegestaan:

a. dit door WFSR uitgebrachte rapport gedeeltelijk te publiceren of op andere wijze gedeeltelijk openbaar te maken;

b. dit door WFSR uitgebrachte rapport, c.q. de naam van het rapport of WFSR, geheel of gedeeltelijk te doen gebruiken ten behoeve van het instellen van claims, voor het voeren van gerechtelijke procedures, voor reclame of antireclame en ten behoeve van werving in meer algemene zin;

c. de naam van WFSR te gebruiken in andere zin dan als auteur van dit rapport.

Postbus 230, 6700 AE Wageningen, T 03174802 56, E info.wfsr@wur.nl, www.wur.nl/food-safetyresearch. WFSR is onderdeel van Wageningen University \& Research.

WFSR aanvaardt geen aansprakelijkheid voor eventuele schade voortvloeiend uit het gebruik van de resultaten van dit onderzoek of de toepassing van de adviezen.

WFSR-rapport 2021.013

Verzendlijst:

- P. Suijker, NVWA

- H.J. Smit, LNV 


\section{Inhoud}

Woord vooraf $\quad 5$

$\begin{array}{ll}\text { Samenvatting } & 7\end{array}$

1

$\begin{array}{lr}\text { Inleiding } & 9\end{array}$

2

$\begin{array}{ll}\text { Materiaal en methoden } & 10\end{array}$

3

$\begin{array}{ll}\text { Resultaten } & 11\end{array}$

3.1 Glasvezels $\quad 11$

3.2 Zware metalen en organische microverontreinigingen, dioxines en PAK's, minerale olie $\quad 11$

3.3 Siliconen-verbindingen $\quad 12$

4

$\begin{array}{ll}\text { Discussie } & 13\end{array}$

$4.1 \quad$ Glasvezels $\quad 13$

4.2 Zware metalen en organische microverontreinigingen, dioxines en PAK's,
minerale olie

$\begin{array}{lll}4.3 & \text { Siliconen-verbindingen } & 14\end{array}$

5

Conclusie

15

Bijlage 1 Resultaten co-materialen tool WFSR analysenummer 200610280

Bijlage 2 Resultaten co-materialen tool WFSR analysenummer 200610281 



\section{Woord vooraf}

WFSR voert jaarlijks duizenden analyses uit om de Nederlandse Voedsel- en Warenautoriteit (NVWA) te ondersteunen bij het handhaving op wettige wettelijke verplichting op het gebied van voedsel, diervoeder en consumentenveiligheid. Dit onderzoek is uitgevoerd door WFSR in opdracht van de NVWA ter controle of het verantwoord is dat gipspoeder, verkregen door verwerking van gipshoudend bouwmateriaal, in de landbouw toegepast wordt. 


\section{Samenvatting}

Sinds januari 2019 is het in Nederland toegestaan om de reststof die bij het gecontroleerd herwinnen van calciumsulfaat als fijn poeder uit gipshoudend sloopafval te gebruiken als meststof mits het gezuiverd is door sortering, verkleining, breken, vermalen en zeven, handmatige zuivering en verwijdering van ijzer middels magneetscheiding. Dit onderzoek is uitgevoerd als een evaluatie van de risico's bij het gebruik van gipspoeder voor landbouwdoeleinden. Er zijn twee gipsmonsters onderzocht op aanwezigheid van contaminanten volgens bijlage Ab tabel 1 en 2 van de Uitvoeringsregeling Meststoffenwet. (Zware metalen en organische microverontreinigingen, dioxines en PAK's, minerale olie), glasvezel en siliconen-verbindingen. Het betreft één monster bestemd voor toepassing in de landbouw en één monster niet bestemd voor toepassing in de landbouw. Uitgaande van de maximaal toegestane depositie op landbouwgrond geven de bevindingen op basis van deze beperkte verkenning geen aanleiding om te concluderen dat gezuiverd afvalgips niet in de landbouw toegepast zou kunnen worden. 


\section{$1 \quad$ Inleiding}

Bijlage Aa. behorende bij artikel 4 van de Uitvoeringsregeling Meststoffenwet staat toe dat reststof die vrijgekomen is bij het gecontroleerd herwinnen van calciumsulfaat als fijn poeder uit gipshoudend sloopafval via zuivering door sortering, verkleining, breken, vermalen en zeven, handmatige zuivering en verwijdering van ijzer middels magneetscheiding gebruikt mag worden als meststof. De reststof bestaat uit gips en inerte materialen afkomstig van natuurgips en organische stof van papier of karton (herwonnen gipspoeder).

Doel van dit onderzoek is een evaluatie van de risico's bij het gebruik van gipspoeder voor landbouwdoeleinden. Het gipspoeder is een restproduct ontstaan bij de verwerking van bouwmateriaal afkomstig uit slooppanden. De vraag is of het verantwoord is als dit materiaal gebruikt wordt als bodemverbeteraar op landbouwgrond.

Hiertoe zijn door WFSR twee monsters gipspoeder onderzocht op aanwezigheid van contaminanten volgens bijlage Ab tabel 1 en 2 van de Uitvoeringsregeling Meststoffenwet, glasvezel en siliconenverbindingen: één monster van gips dat bestemd is voor toepassing in de landbouw en één monster niet bestemd voor toepassing in de landbouw. 


\section{Materiaal en methoden}

De onderzochte twee gips monsters zijn d.d. 3 december 2020 bij WFSR aangeleverd, één bestemd voor gebruik in de landbouw (WFSR analysenummer 200610280) en één niet bestemd voor gebruik in de landbouw (WFSR analysenummer 200610281), na bemonstering door de NVWA bij Gipsnet BV te Gorinchem.

In overleg met de NVWA is besloten tot onderzoek van de gipsmonsters op de volgende parameters:

- Aanwezigheid van glasvezels vanwege de risico's met fijnstof

- Aanwezigheid van stoffen vermeld in de bijlage Ab tabel 1 en 2 bij de Uitvoeringsregeling Meststoffenwet (Zware metalen en organische microverontreinigingen, dioxines en PAK's, minerale olie)

- Aanwezigheid van siliconen-verbindingen vanwege mogelijke toxicologische risico's

Met gebruik van microscopische technieken is er onderzocht of er glasvezel in de monsters aanwezig is en is er een schatting gedaan van het gehalte glasvezel in de monsters.

Daarnaast is er gebruik gemaakt van de WFSR Rekentool Co-materialen. Met behulp van deze rekentool kan worden vastgesteld of de maximale toegestane belasting van landbouwgrond, op basis van het waarde-gevend bestanddeel, leidt tot een overschrijding van de normen voor in het product aanwezige contaminanten. Bedoeld zijn de contaminanten zoals genoemd in bijlage Ab tabel 1 en 2 van de Uitvoeringsregeling Meststoffenwet.

Verder is door Norwegian Institute for Air Research (NILU) de aanwezigheid van polydimethylsiloxaan verbindingen in de monsters onderzocht om een indicatie te krijgen van de aanwezigheid van siliconen-verbindingen in de gips monsters. Deze stoffen kunnen aanwezig zijn doordat deze gebruikt worden bij de productie van waterbestendige gipsplaten. 


\section{Resultaten}

\subsection{Glasvezels}

Met microscopische technieken is eenduidig de aanwezigheid van glasvezels in beide monsters aangetoond, zie figuur 1. Een indicatief gehalte: 1 tot 5 massaprocenten. Uitgaande van de toegestane depositie van het materiaal, berekend op $10.000 \mathrm{~kg} / \mathrm{ha}$, betekent dit maximaal $500 \mathrm{~kg}$ glasvezel per hectare. Het aanwezige glas bestaat uit vezels van $500 \mu \mathrm{m}$ lengte en groter, soms in bundels aanwezig, en met een vezeldiameter van 15 tot $20 \mu \mathrm{m}$.

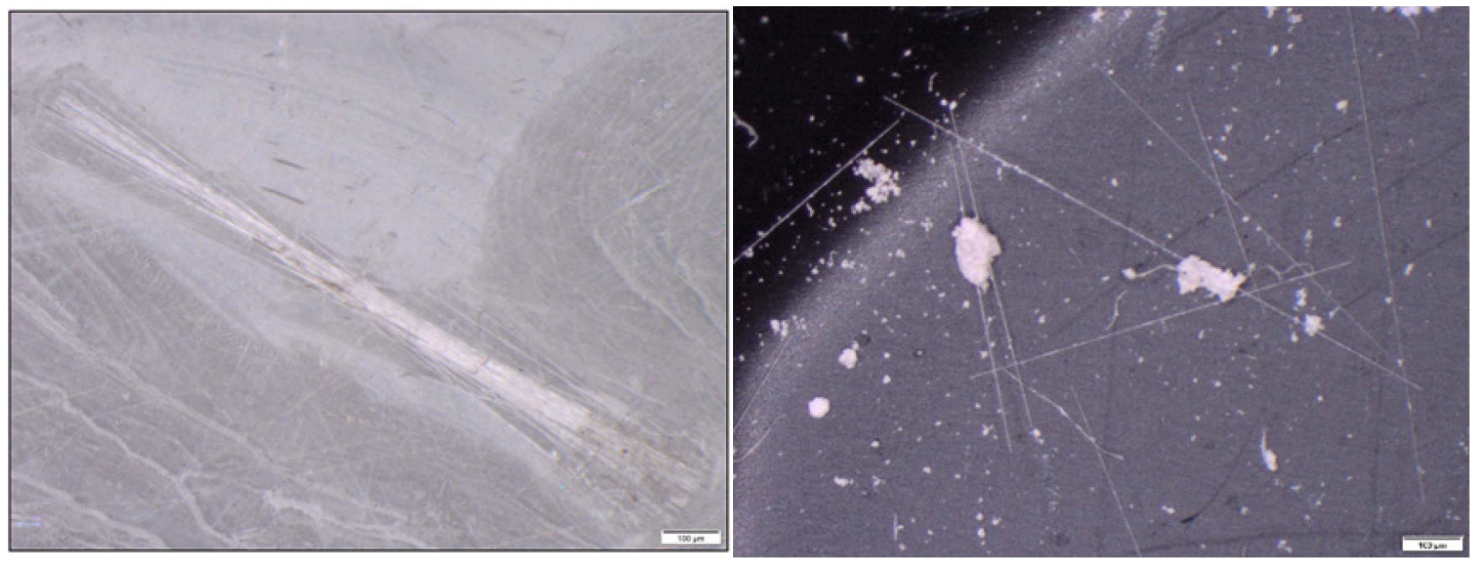

Figuur 1 Bundel glasvezels (links) en los liggende glasvezels met restanten matrix (rechts).

\subsection{Zware metalen en organische microverontreinigingen, dioxines en PAK's, minerale olie}

De analyseresultaten op de contaminanten zoals genoemd in bijlage Ab tabel 1 en 2 van de Uitvoeringsregeling Meststoffenwet zijn weergegeven in de bijlagen 1 resp. 2 . De uitwerking van de analyseresultaten met de Co-materialen Rekentool geeft als waarde-gevend bestanddeel de "neutraliserende waarde" (\% CaO in product). Dit is het bestanddeel waarop voor dit product de toetsing wordt gedaan. Als gevolg van het ontbreken van specifieke regelgeving voor afvalgips wordt hier gebruik gemaakt van criteria die gesteld worden aan co-materialen bij vergisting waarbij het eindproduct ook als meststof toegepast wordt.

Toetsing met de Co-materialen Rekentool geeft aan dat voor geen van de componenten in bijlage Ab tabel 1 en 2 een normoverschrijding plaatsvindt bij maximaal toegestane depositie op landbouwgrond. Het monster, niet bestemd voor landbouw toepassing, bevat ongeveer een factor 8 meer dioxines dan het monster bestemd voor landbouw. In beide gevallen is de hoofdcomponent OCDD: 90\% van het totaal aan dioxines. 


\subsection{Siliconen-verbindingen}

In tabel 1 staan de kwantitatieve analyseresultaten voor polydimethylsiloxaan verbindingen weergegeven.

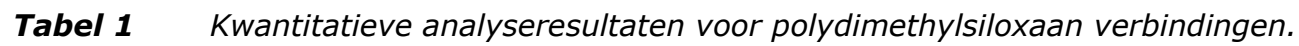

\begin{tabular}{lll}
\hline Component & WFSR nr. & 200610281 \\
& 200610280 & $(\mathrm{ng} / \mathrm{g})$ \\
\hline D4 - Octamethylcyclotetrasiloxane & $(\mathrm{ng} / \mathrm{g})$ & 1.6 \\
\hline D5 - Decamethylcyclopentasiloxane & $0.4(<\mathrm{LOQ})^{*}$ & 26.8 \\
\hline D6 - Docedamethylcyclohexasiloxane & 20.1 & 31 \\
\hline L3 - Octamethyltrisiloxane & 14.9 & $0.1(<\mathrm{LOQ}) *$ \\
\hline L4 - Decamethyltetrasiloxane & $0.2(<$ LOQ $) *$ & niet aangetoond \\
\hline L5 - Dodecamethylpentasiloxane & niet aangetoond & 4.5 \\
\hline M3T(Ph) - tris(trimethylsiloxy)phenylsilane & 1.7 & 0.3 \\
\hline
\end{tabular}

*Resultaat beneden de kwantificeringsgrens

Daarnaast is een kwalitatieve analyse uitgevoerd op L6 tot L9 en de D7 tot D9 siloxanen om een indruk te krijgen van de aanwezigheid van de langere keten siloxaan verbindingen. Voor deze groep verbindingen heeft het NILU geen kwalitatieve methode beschikbaar. Bij de gehanteerde methode worden onder meer retentietijd en het massaspectrum vergeleken met in de internationale NIST bibliotheek opgeslagen data. Bij een zoekopdracht in de NIST bibliotheek worden in het monster gemeten parameters vergeleken met in de bibliotheek vastgelegde parameters. Een mathematische berekening wordt gedaan die een indicatieve uitspraak doet over de kwaliteit van de overeenkomst: de "match probability". In onderstaande tabel zijn de resultaten weergegeven.

Tabel 2 Kwalitatieve analyseresultaten polydimethylsiloxaan verbindingen.

\begin{tabular}{lll} 
Component & $\begin{array}{l}\text { Retention time } \\
(\text { min) }\end{array}$ & $\begin{array}{l}\text { NIST library } \\
\text { match probability }\end{array}$ \\
\hline 1,3-bis(1,1-Dimethylethyl)benzene & 11.49 & $65 \%$ \\
\hline Tetradecamethylhexasiloxane (L6) & 13.19 & $67 \%$ \\
\hline Tetradecamethylcycloheptasiloxane (D7) & 14.02 & $83 \%$ \\
\hline Hexadecamethylheptasiloxane (L7) & 14.65 & $66 \%$ \\
\hline Hexadecamethylcyclooctasiloxane (D8) & 15.33 & $77 \%$ \\
\hline Octadecamethylcyclononasiloxane (D9) & 16.31 & $53 \%$ \\
\hline
\end{tabular}




\section{Discussie}

\subsection{Glasvezels}

Glas is een chemisch vrijwel inert materiaal, is niet toxisch en heeft geen bekende carcinogene of mutagene eigenschappen. Glasvezels zijn echter wel irriterend bij contact met huid en/of ogen. Een gezondheidsrisico ontstaat als het respirabele vezels betreft: het inademen van fijn stof kan op den duur lijden tot mechanische beschadigingen diep in het longweefsel met ontstekingsreacties en fibrose tot gevolg. Fibrose kan uiteindelijk leiden tot de ontwikkeling van kanker. Hierbij zijn de afmetingen van de vezels van belang: vezels kleiner dan $3 \mu \mathrm{m}$ en een lengte/doorsnede verhouding van max. 3 kunnen diep genoeg in longblaasjes doordringen.

De aangeboden monsters bevatten 1 tot 5 massaprocenten glasvezels. Deze bestaan uit vezels van minimaal $500 \mu \mathrm{m}$ lengte en groter, soms in bundels aanwezig, en met een vezel-diameter van 15 tot $20 \mu \mathrm{m}$. De vezels in het onderzochte materiaal vallen daarmee qua afmetingen niet binnen de risicocategorie. Verdere verwerking van het materiaal kan echter wel van invloed zijn op de vorming van fijnstof. Het risico ligt in het verwerkingsproces tot en met depositie van het eindproduct op het land. Hierbij moet inademing van (fijn) stof worden voorkomen en moet aandacht worden besteed aan een adequate bescherming bij beroepsmatige blootstelling.

\subsection{Zware metalen en organische microverontreinigingen, dioxines en PAK's, minerale olie}

Op basis van de resultaten van de Co-materialen Rekentool kan eventueel een kanttekening worden geplaatst bij de aanwezigheid van dioxines in het materiaal. In beide monsters zijn dioxines aangetroffen, hoofdzakelijk OCDD: $90-95 \%$ van het totaal aan dioxines. Het monster bestemd voor landbouwdoeleinden geeft een overschrijdingsfactor van 0,1. Het monster niet bestemd voor landbouwdoeleinden geeft een overschrijdingsfactor 0,4. De grenswaarde ligt bij een overschrijdingsfactor 1 . Het verschil in gehalte geeft het belang aan van effectieve scheiding van mogelijk gecontamineerd materiaal (b.v. afkomstig uit bouwafval met brandschade) in het selectietraject voor materiaal bestemd voor toepassing in de landbouw. Op basis van metingen aan twee monsters, één afkomstig uit de partij bestemd voor landbouwtoepassing en één uit de partij niet bestemd voor toepassing op landbouwgrond is de efficiëntie van het scheidingsproces moeilijk in te schatten. Dioxines zijn hydrofoob en hebben een geringe vluchtigheid en worden daardoor sterk geabsorbeerd aan deeltjes in de bodem. Dioxines worden in het milieu nauwelijks afgebroken en zullen accumuleren in de bodem. 


\subsection{Siliconen-verbindingen}

Gezien het wijdverspreide gebruik van siloxanen bij een groot aantal toepassingen zijn ze wijdverspreid in het milieu, zij het in zeer lage concentraties. De korte-keten siloxanen zijn buitengewoon vluchtig en worden vrij gemakkelijk uit de bodem verwijderd. Bij het op het land brengen zal het grotendeels (80-85\%) vervluchtigen. D4, D5 en D6 hebben toxische effecten op het biologische reproductie-proces en hebben een verstorende werking op estrogene en androgene processen. Siloxanen met een hoog molecuulgewicht zijn niet vluchtig. Ze diffunderen niet door celmembranen en bio-accumulatie is niet aangetoond. Uit onderzoek is gebleken dat ze in de bodem afgebroken kunnen worden tot kleinere eenheden.

In beide gipsmonsters zijn zowel D4 als D5 en D6 aangetoond, D4 is aangetoond bij het monster bestemd voor toepassing in de landbouw op een niveau beneden de kwantificeringsgrens (LOQ: Limit of Quantification). Uitgaande van de toegestane depositie van het materiaal, berekend op $10.000 \mathrm{~kg} / \mathrm{ha}$, betekent dit een belasting van ca. $200 \mathrm{mg}$ D5 resp. $149 \mathrm{mg}$ D6 per hectare. Of, rekening houdend met $80 \%$ vervluchtiging, $40 \mathrm{mg}$ D5 resp. $30 \mathrm{mg}$ D6 per hectare.

Vergelijkenderwijs: In Volatile Methylsiloxanes in the Environment (Homem, V. \& Ratola, N., 2020) wordt een dagelijkse humane blootstelling aan siloxanen gemeld van 0.6 tot $4.65 \mathrm{mg}$ per persoon, onder meer via cosmetica en toiletartikelen, zonnebrandolie en door inademing. In het stedelijke milieu worden ook vluchtige siloxanen aangetroffen, zie onderstaande tabel.

Tabel 3 Humane blootstelling aan D4, D5 en D6 volgens Volatile Methylsiloxanes in the Environment (Homem, V. \& Ratola, N., 2020).

\begin{tabular}{lccc} 
Locatie luchtmonster & $\mathrm{D} 4\left(\mu \mathrm{g} / \mathrm{m}^{3}\right)$ & $\mathrm{D} 5\left(\mu \mathrm{g} / \mathrm{m}^{3}\right)$ & $\mathrm{D} 6\left(\mu \mathrm{g} / \mathrm{m}^{3}\right)$ \\
Rioolwater zuiveringsinstallatie & 4.1 & 2.4 & 2.1 \\
\hline Stedelijke centra & 2.1 & 0.93 & 0.39 \\
\hline
\end{tabular}




\section{$5 \quad$ Conclusie}

Zowel bij gebruik van zowel het monster dat bedoeld is voor landbouwtoepassing, als het monster dat niet bedoeld is voor landbouwtoepassing vindt er voor geen van de componenten in bijlage Ab tabel 1 en 2 van de Uitvoeringsregeling Meststoffenwet een normoverschrijding plaats uitgaande van de maximaal toegestane depositie op landbouwgrond.

Het vóórkomen van dioxines in het materiaal, en de gevonden concentratie-verschillen tussen de beide monsters is wel een punt van aandacht. Omdat slechts één monster per type materiaal beschikbaar was kan geen uitspraak worden gedaan over de representativiteit van het monster voor de gehele partij.

De gipsmonsters bevatten 1 tot 5 massaprocenten glasvezels, echter vallen deze qua afmetingen niet binnen de risicocategorie. Desalniettemin is de aanbeveling inademing van (fijn) stof te vermijden en aandacht te besteden aan een adequate bescherming bij beroepsmatige blootstelling.

De vluchtige methylsiloxanen worden gezien als een nieuwe groep milieucontaminanten en zijn als zodanig onderwerp van onderzoek. Op basis van de huidige kennis van toxische effecten van deze stoffen en de wijze waarop ze zich verspreiden in het milieu lijkt terughoudendheid bij toepassing van gecontamineerde materialen op landbouwgrond gepast. Normstelling op dit gebied ontbreekt.

De bevindingen op basis van deze beperkte verkenning geven geen aanleiding om te concluderen dat afvalgips niet in de landbouw toegepast zou kunnen worden. 


\section{Bijlage 1 Resultaten co-materialen tool WFSR analysenummer 200610280}

Rekenblad ter beoordeling overschrijding normen meststoffenwet

DIIKILT

WAGENINGENUR

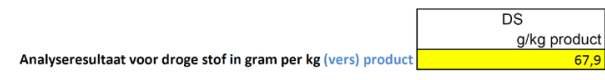

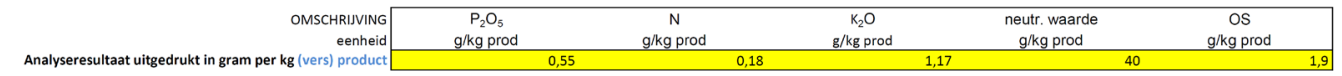

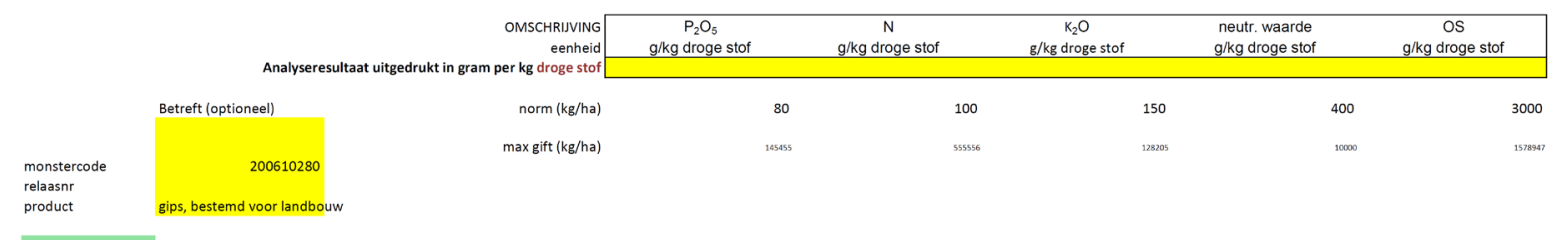

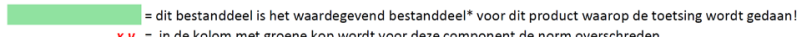

$y=$ in de kolom met groene kop wordt voor deze component de norm overschreden

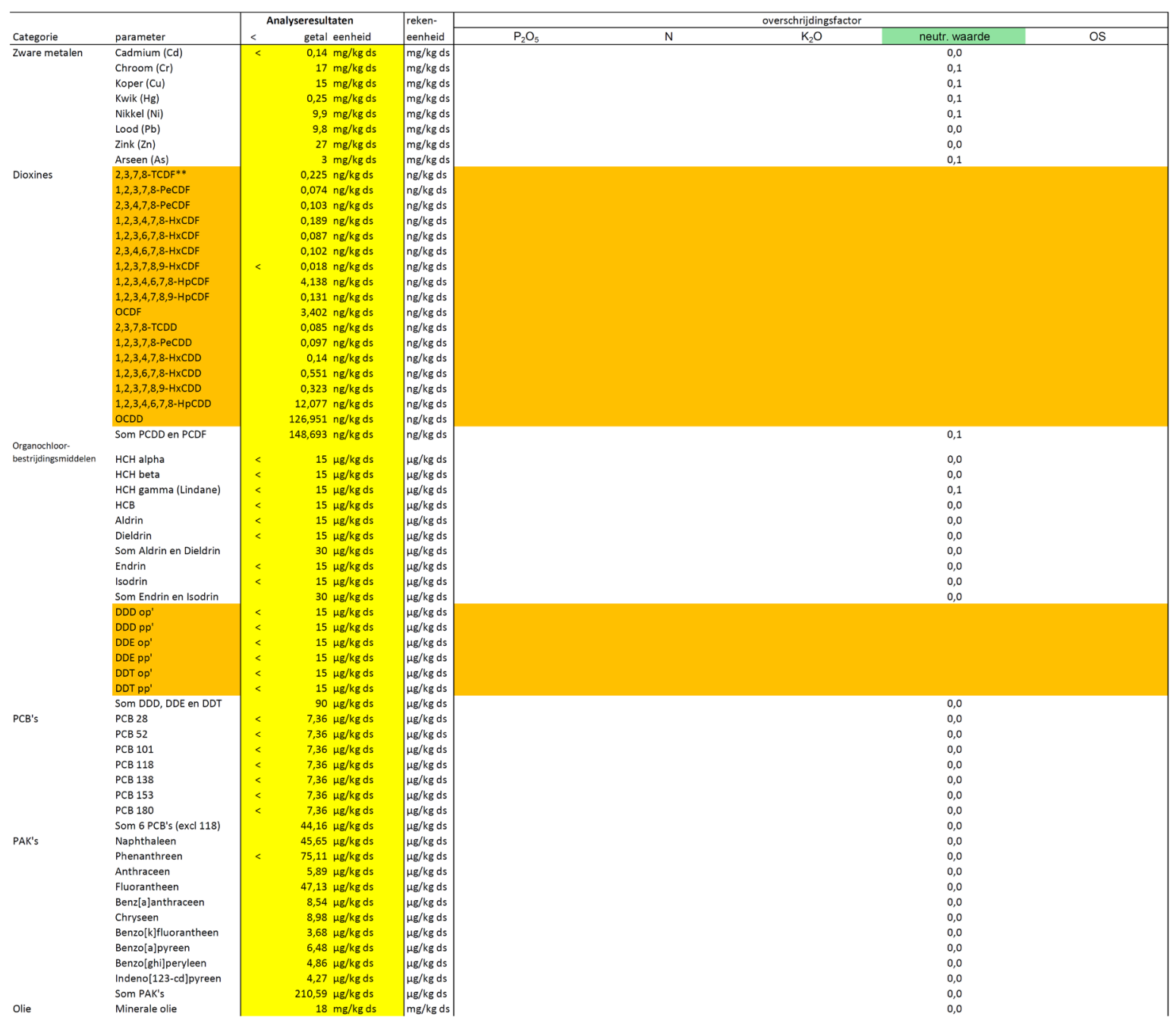

onder waardegevende bestanddelen worden verstaan fosfaat (P2O5), stikstof (N), kali (K2O), neutraliserende waarde (uitgedrukt als g CaO/kg) (neutr. waarde) en organische stof (OS).

analyserestatatingevuld conform rapeortase van het lab. 


\section{Bijlage 2 Resultaten co-materialen tool WFSR analysenummer 200610281}

Rekenblad ter beoordeling overschrijding normen meststoffenwet

RIKILT

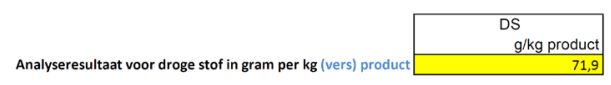

\begin{tabular}{|c|c|c|c|c|c|}
\hline $\begin{array}{r}\text { OMSCHRIVING } \\
\text { eenheid } \\
\text { Analyseresultaat uitgedrukt in gram per } \mathrm{kg} \text { (vers) product }\end{array}$ & \multicolumn{2}{|c|}{$\begin{array}{cc}\mathrm{P}_{2} \mathrm{O}_{5} & \mathrm{~N} \\
\mathrm{~g} / \mathrm{kg} \text { prod } & \mathrm{g} / \mathrm{kg} \text { prod } \\
\end{array}$} & $\begin{array}{c}\mathrm{K}_{2} \mathrm{O} \\
\mathrm{g} / \mathrm{kg} \text { prod }\end{array}$ & $\begin{array}{l}\text { neutr. waarde } \\
\text { g/kg prod }\end{array}$ & $\begin{array}{c}\text { OS } \\
\text { g/kg prod }\end{array}$ \\
\hline
\end{tabular}

\begin{tabular}{|c|c|c|c|c|c|c|c|}
\hline & & $\begin{array}{r}\text { OMSCHRIJVING } \\
\text { eenheid }\end{array}$ & $\begin{array}{c}\mathrm{P}_{2} \mathrm{O}_{5} \\
\mathrm{~g} / \mathrm{kg} \text { droge stof }\end{array}$ & $\begin{array}{c}\mathrm{N} \\
\mathrm{g} / \mathrm{kg} \text { droge stof }\end{array}$ & $\begin{array}{c}\mathrm{K}_{2} \mathrm{O} \\
\mathrm{g} / \mathrm{kg} \text { droge stof }\end{array}$ & $\begin{array}{l}\text { neutr. waarde } \\
\mathrm{g} / \mathrm{kg} \text { droge stof }\end{array}$ & $\begin{array}{c}\text { OS } \\
\mathrm{g} / \mathrm{kg} \text { droge stof }\end{array}$ \\
\hline & Betreft (optioneel) & norm (kg/ha) & 80 & 100 & 150 & 400 & 3000 \\
\hline $\begin{array}{l}\text { monstercode } \\
\text { relaasnr } \\
\text { product }\end{array}$ & $\begin{array}{c}200610281 \\
\text { gips, niet bestemd voor landbouw }\end{array}$ & $\max \operatorname{gift}(\mathrm{kg} / \mathrm{ha})$ & :55846 & s000000 & 85714 & $\infty 000$ & 1355360 \\
\hline
\end{tabular}

$=$ dit bestanddeel is het waarde gevend bestanddeel* voor dit product waarop de toetsing wordt gedaan!

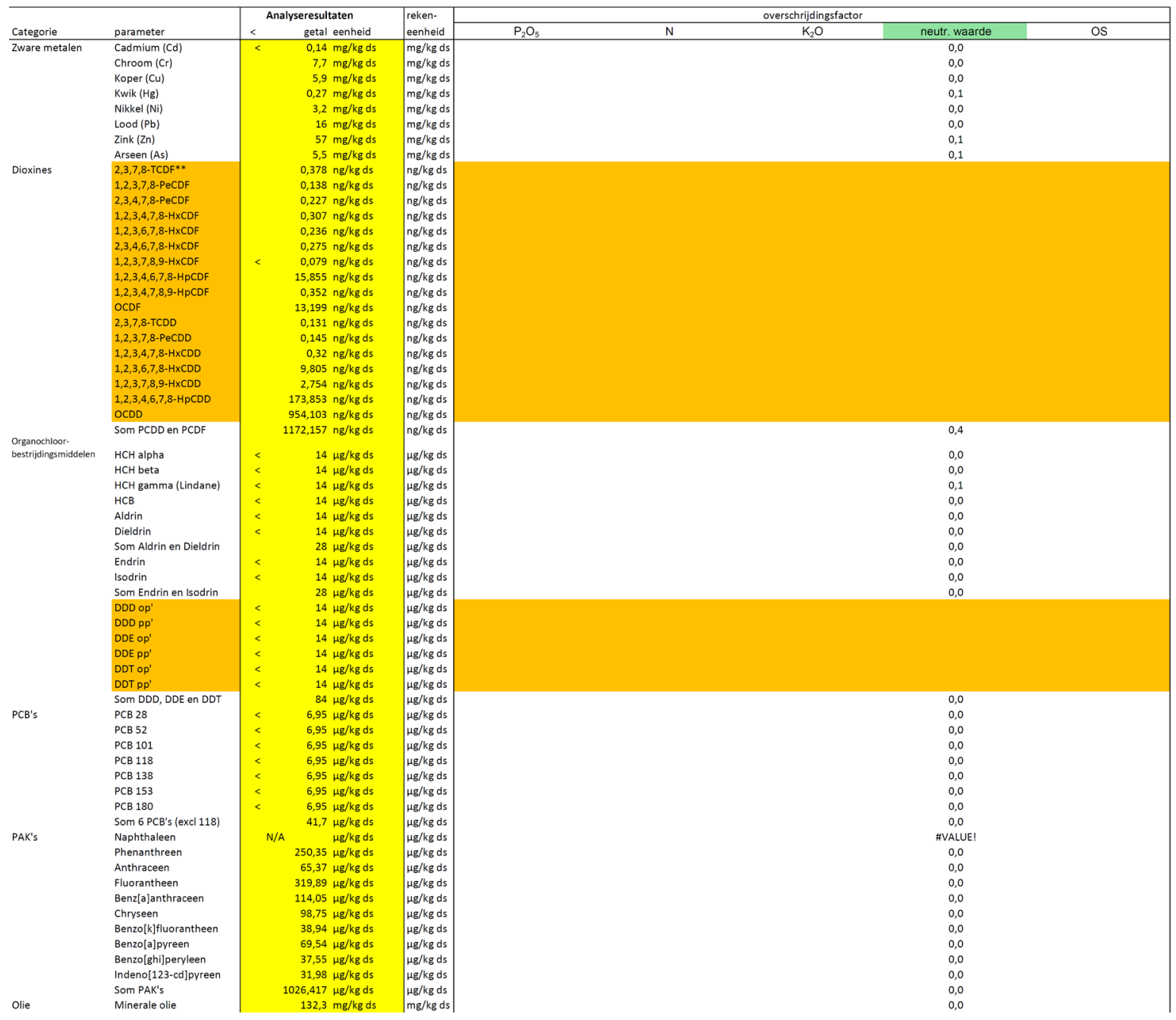

onder waardegevende bestanddelen worden verstaan fosfaat (P2O5), stikstof (N), kali (K2O), neutraliserende waarde (uitgedrukt als g CaO/kg) (neutr. waarde) en organische stof (OS).

individuele componenten worden wel geanalyseerd, toetsing alleen op som. 
Wageningen Food Safety Research Postbus 230

6700 AE Wageningen

T 0317480256

www.wur.nl/food-safety-research

WFSR-rapport 2021.013
De missie van Wageningen University \& Research is 'To explore the potential of nature to improve the quality of life'. Binnen Wageningen University \& Research bundelen Wageningen University en gespecialiseerde onderzoeksinstituten van Stichting Wageningen Research hun krachten om bij te dragen aan de oplossing van belangrijke vragen in het domein van gezonde voeding en leefomgeving. Met ongeveer 30 vestigingen, 6.800 medewerkers ( $6.000 \mathrm{fte}$ ) en 12.900 studenten behoort Wageningen University \& Research wereldwijd tot de aansprekende kennisinstellingen binnen haar domein. De integrale benadering van de vraagstukken en de samenwerking tussen verschillende disciplines vormen het hart van de unieke Wageningen aanpak.

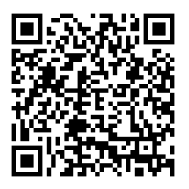





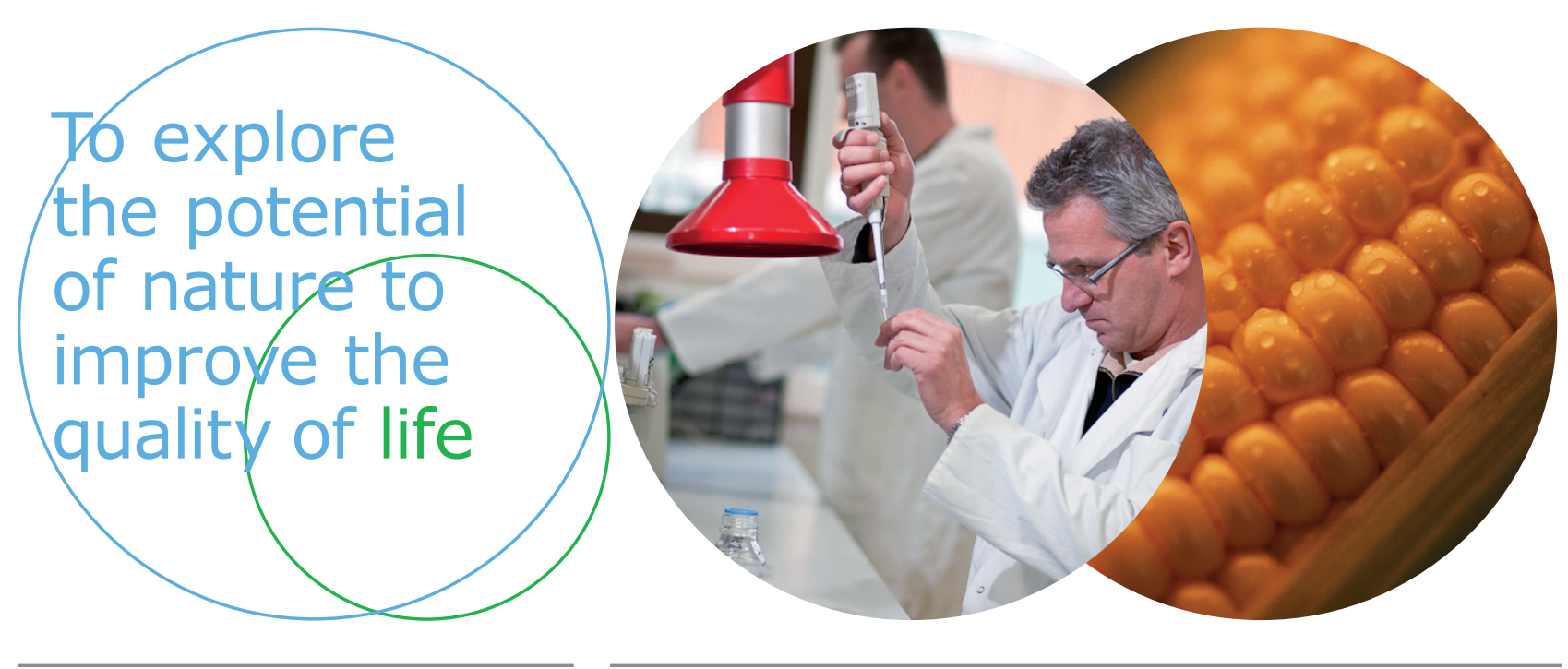

Wageningen Food Safety Research Postbus 230

6700 AE Wageningen

T 0317480256

www.wur.nl/food-safety-research

WFSR-rapport 2021.013
De missie van Wageningen University \& Research is 'To explore the potential of nature to improve the quality of life'. Binnen Wageningen University \& Research bundelen Wageningen University en gespecialiseerde onderzoeksinstituten van Stichting Wageningen Research hun krachten om bij te dragen aan de oplossing van belangrijke vragen in het domein van gezonde voeding en leefomgeving. Met ongeveer 30 vestigingen, 6.800 medewerkers (6.000 fte) en 12.900 studenten behoort Wageningen University \& Research wereldwijd tot de aansprekende kennisinstellingen binnen haar domein. De integrale benadering van de vraagstukken en de samenwerking tussen verschillende disciplines vormen het hart van de unieke Wageningen aanpak. 